\title{
Design tourist planning in Colombian lagged destination: Case study Bahía Solano
}

\author{
Gabriela Antošová \\ Department of economics, University the College of business in Prague \\ Jefferson Enrique Arias Gomez \\ Rector office, Corporación Minuto de Dios, Bogotá \\ Helmuth Yesid Arias Gomez \\ Department of economics, University the College of business in Prague
}

Received: 7 October 2019. Revision received: 15 November 2020. Accepted: 3 December 2020

\begin{abstract}
This article aims to explore the emergency in tourism activities linked with a landscape in a lagged west area of Colombia, specifically in the town of Bahía Solano. The main objective is to describe values in the qualitative explorative case study for proposing the tourism management process to the whole organization of activities in the lagged area as Bahía Solano. In spite of the isolation and lack of connectivity, the spontaneous market mechanism and the flow of visitors contributed to a continuous development of economic activities that deep changes in local life. In consideration of initial conditions of the town, our approach poses interesting challenges which are exposed here. Firstly, we inquire about the possible effects of tourism on lagged places with a qualitative exploratory study and we built profiles of local and foreign visitors interpreting their features and their expectations regarding this kind of destination. This territory has much to attract tourism got with whale watching, birds watching and so one. A lot of activities haven't got the technology planning process and are scarcely promoted, tourism guidelines or safety tourism design process. This article results the design tourism process planning as an opportunity to implement to the Pacific Ocean destination of Bahía Solano and will be used in the municipality as a part of the next step for the municipality tourism plan.
\end{abstract}

Key Words: design tourism, sustainability, territory planning, indigenous people, Pacific Ocean

JEL Classification: R58, Z32, O54

\section{Introduction}

This article captured the assessment of visitors' experiences and perception during a journey to the zone of Colombia and suggested the "technology tourism planning" for the zone. The proposal of this research stems from the bilateral research in the Colombian department of Chocó, specifically on the coastline of the Pacific Ocean in Bahía Solano. In this territory, the Colombian post-conflict era had a significant effect on the current local development (Çakmak \& Isaac, 2016) and also on the upsurge of tourism activities. Furthermore, this geographic location has great potential in terms of nature, history and also environmental attributes. We found that indigenous people, need to be supported by exogenous approaches to improve the design of the touristic plan, as preserved places and 
nature parks have an increasing number of tourism activities. We found a number of unstable lifestyles and other socio-economic necessities, which have to be improved.

As a background, Czech scientists previously implemented a methodology used in Czech border areas (Gómez \& Antošová, 2014) to improve the tourist destinations after the downfall of the Iron Curtain. The transition of these strategies to Bahía Solano might well contribute to the future design for a local tourism plan and improve the Colombian strategy. By applying the Czech approach of development as a model, observing and understanding the perceptions of international tourists, we hope that it will underpin the consolidation of an acceptable border/coastline plan that will with promote positive changes in this distinctly remarkable region on the Pacific Ocean.

The final product will be to formulate a tourism plan developed collaboratively by Czech and Colombian researchers, which employs a multidisciplinary approach. Specifically, our aim is to find the solutions required for designing a unique plan for Bahía Solano, a Post-Conflict zone in the region of Chocó.

Consequently, an increasing number of tourists need to arrange their visits, while simultaneously, organizations and stakeholders of the destinations want to improve their tourism availability. This article is a part of a broader research: "Bahía Solano como destino turístico", which looks for a design-process for this destination. The participatory design could influence the local development, and also the quality of life of the indigenous people. In this lagged or poor destination with a high international tourism potential, these individuals still seek professional engagement within their region.

In this study we analyze an emerging destination and the tourism activities linked with the natural landscape in a lagged area in western Colombia, specifically the municipality of Bahia Solano. In spite of the isolation and lack of connectivity with other areas, spontaneous market mechanisms and flow of visitors have contributed to the continuous development of economic activities generating significant changes in the local life of its residents. In consideration of the initial conditions of the municipality of Bahía Solano, our approach possesses a number of interesting challenges.

First, we will inquire about the possible effects of tourism on lagged geographical locations, while applying the statistical tools of SPSS software and processing primary data from the questionnaires. From this we will build profiles of local and foreign visitors, interpreting their characteristics and expectations about this destination. Moreover, we plan to consult basic cartographic information which is extracted from geographical and statistical authorities: IGAC (Instituto Geográfico Agustín Codazzi) and DANE (Departamento Administrativo Nacional de Estadística), to provide a functional map of GDP per capita.

The second step is the process of designing a technology and tourism plan within an intercontinental context. We believe that the design of a technology-tourism plan can be an opportunity to implement a set of strategies to promote the development of Bahía Solano, as a Pacific Ocean destination. Furthermore, this territory is endowed with abundant tourism offerings, such as whale and bird watching, beach activities, nature walks, and other features for visitors. A number of commodities lacks a technology and planning process with technical development, as applied to tourism guidelines or safety tourism design processes. In addition, Bahía Solano has rarely been advertised in a target tourism market. Based on our qualitative explorative analysis, we will propose realistic improvements for the tourism management process and the organizational activities within the lagging municipality of Bahía Solano.

We explore an interesting case uncovering the exploitation of marginalized individuals residing in an isolated destination of Colombia and where they are suddenly 
facing an abundant flow of tourists attracted by the natural landscape, relaxing environment, and overall beauty of that region. Particularly poignant and central to our study is that these potential tourism activities emerged in the poor region of Choco in Colombia with enormous disadvantages in comparison with those in other central regions. In those terms, we propose to tackle the analysis from a perspective of a pro-poor tourism approach to the municipality of Bahía Solano. The analysis is interesting, providing potential of the area that is projected as an appealing tourism destination, including the pressing necessity to overcome the social and economic lag of this region. Moreover, in the context of a Post-Conflict reality in Colombia, there is the challenge to promote and design a developmental process in this region, formerly affected by different kinds of violence.

The empirical part of the study centers on Bahía Solano municipality located on the Colombian Pacific coast, and belongs to the district (department) of Chocó. This case is a typical situation in which the spontaneous market process and authentic supply and demand dynamics precede any kind of political intervention and design planning action. In this selected destination residents were surprised by a sudden flow of tourists exploring amid incredible nature scenery, but unfortunately that was in the context of a lagged, poor social and economic region. Using the Directory of National Natural Parque Utría as a source, the tourism boom during a ten-year period from 2007 to 2017 was increased from 538 to 7342 visitors. However, the local tourism demand was matched by an insufficient tourism infrastructure, and almost non-existent possibilities of physical access to the region.

Even today, there are only two types of transportation routes: one by riverboats or another by airplane (operated by airlines SATENA and ADA, according to Bahiasolanoaldia.com and Easyfly, which started operation at the end of 2018). Looking forward, comprehensive, public policy action must be implemented with the purpose of promoting a design for local development as we have inspired in other regions of Colombia (Escobar, 2018), and for adapting the physical planning and social-economic priorities to the current tourism boom in the observed destination of our study.

With the purpose of exposing the tourism dynamic in a selected destination, we structured this article according to the following: First, we present several ideas discussed in the cadre of pro-poor tourism theory and the designing of destination tourism. The second section displays the general context of design tourism activities in Colombian enterprises. The third section connects with the theoretical discussion, which addresses exposes the social and economic situation of the region. In the fourth part, we apply the outcomes of basic data collected by questionnaires, and perform statistical procedures of optimal scaling in order to project basic profiles of visitors in this destination. Finally, we provide several design activities for the municipality and our conclusions for the design planning.

\section{Literature review}

The topic of analysis focuses on interesting phenomena related to tourism. We chose a lagged destination affected by economic, social adversities and formerly a scenario of violent confrontation between several illegal bands. This background, possesses a particular interest on such topic, not only from the touristic point of view, but as a case study in lagged areas, where tourism can be act as a vehicle for overcoming adversity, offering economic opportunities to the poor people. 


\subsection{Tourism and poverty relief}

Several documents expose the role of touristic activities contributing to the reduction of poverty (Sustainable development goals Agenda 2030 - Goal 1 End poverty in all its forms everywhere), not only at an academic level, but more importantly, as a discussion made by international institutions and in some cases by the governments (ILO International labor office, 2018; Organización Mundial del Turismo Madrid, 2003). In such discussions, the term pro-poor tourism comes up (Ashley, Boyd, \& Goodwin, 2016; Holland, Burian, \& Dixey, 2003). Pro-poor is an adjective intended to allude strategies focused on impacting openly the conditions of the poor indigene, to enable them to overcome poverty. It deals with a strategy to unlock opportunities for them (Jamieson et al., 2004).

An important design idea in the context of analysis is to guarantee a permanent and definitive insertion of the poor indigene, both young and old into the dynamics derived from the flows of visitors to the lagged areas. It means that the participation of the poor must not be a sporadic intromission and interaction with the visitors, but the role of the poor indigenous could be designed by means of the market mechanism through offering handicrafts, food, tropical fruits, touristic information, etc., having as a precondition for the training of the local human capital. Moreover, in some destinations with low population, the possibility of local prosperity appeals to new inhabitants; so tourism could contribute to stop the out-migration and to foster re-population (Holland et al., 2003).

In contrast, some harmful phenomena come on. An unpleasant outcome on the local life related to boom of touristic activities could be the building of prosperous enclave economy with no links or positive effects on the neighborhood, as in the case of oil and mining exploitations. Moreover, as passes at higher level, local prices tend to rise as consequence of demand pressures coming from the booming activities of tourism (Blake, Arbache, Sinclair, \& Teles, 2010). Also it's recognized that tourism could carry on harmful effects for design societies and local environment, namely: it increases the pressure for natural resources, as water and land could deepen social tensions and cultural disruptions, it could also foster local resentment originated in exclusion from the economic circuits, and could increase the perverse interaction of tourist with local people, particularly in sexual terms (ILO International labor office, 2018). Consequently, successful pro-poor touristic initiatives tend to minimize all harmful effects and enhance its benefits (Holland et al., 2003).

In general, the literature on tourism identifies a negative phenomenon in terms of resources, out warding the lagged region exploited as touristic destination (Jamieson et al., 2004; Organización Mundial del Turismo Madrid, 2003). Those are defined in terms of payments done to enterprises or external agents for goods or services demanded by the tourist in particular, when imports are paid. It occurs because there is no local availability of some commodities asked by the tourist. But in some cases, the same situation could design the business creativity of inhabitants, in order to meet new demands coming from the visitors.

The inclusion of the poor people into the economic stream of touristic services must be an activity with low risk, it means that only in minimally consolidated destinations the poor people can offer services, and on the other hand indigenous people could enhance tourism with their own activities. The pro-poor activities really could be 
developed with the condition of already existent touristic projects, with a continuous flow of visitors, because poor people are not able to take the risk of offering services in uncertain markets (Desarrollo turístico sostenible, 1999). High vulnerability in poor population is commonly acknowledged. They suffer deprivation and normally their participation in the decision making process is insignificant, they lack access to saving and capital and as consequence, their basic needs are not satisfied, and their condition is called ill-being (Jamieson et al., 2004).

In fact, some strategies of promoting the poor people into tourism circuits propend for make-up, for promotion and design of the new activity as a supplementary source of income for the families, in addition to agriculture, fishing or stockbreeding, in order to improve familiar budget (Holland et al., 2003).

This destination shares several specific features with other lagged areas with potential for touristic exploitation. Their natural attractions are really unique, and because of the scarce economic activity, the natural landscape is not yet invaded by human intervention; so in any case, it's well conserved. However, lagged region have important disadvantages in terms of quality of product, accessibility and infrastructure, availability of skills and motivation of investors. Some additional complications arrive in consideration of institutional and political failures, difficulties in dealing with areas with low density of population, etc. (Holland et al., 2003). The poor people exhibit high vulnerability to negative shocks of diverse causes: natural, of health and economic ones, and unfortunately, they are not able to recover quickly from these events (Jamieson et al., 2004).

The pro-poor tourism must be promoted and designed not as a niche sector isolated from the surrounding activities, but as a stream that incorporates the poor into the development (ILO International labor office, 2018). So, the ultimate objective of applying a pro- poor touristic management is the incorporation of the surrounding population into the core activities of the market derived from the touristic activities, but in some destinations, formal and bigger businesses propitiate the physical isolation of these facilities with the purpose of avoiding the contact between the tourists and population (Organización Mundial del Turismo Madrid, 2003).

\subsection{National context of tourism activities}

Provided the huge necessity of the region in social and economic terms, all scales of government recognized the role of tourism as an engine of economic development in a sustainable way. The sustainable development is becoming considerable as a design destination model for areas in the Caribbean (Moore, 2015). In fact, at different scales of Government, public documents incorporate specific plans to boost the tourism sector in the focus region, in spite of that, the previously spontaneous market phenomenon started with specific services to visitors. Both at regional (República de Colombia Ministerio de Comercio, Industria y Turismo, 2016) and local level ("Plan de Desarrollo Bahía Solano," 2016) the public policy exposes the promotion of touristic activities as a priority (we can see on YouTube some videos about tourism in the department of Chocó, especially about the migration of whales or turtles).

In Colombia, opportunities for tourism are enormous, owing to its localization at the North West corner of South America that explains its diversity in climate, landscape, human potential and other topics that enable its touristic supply. In consequence, some authors highlight that it contains high level of earth biodiversity (Mittermeier et al., 1997). 
In those terms, Colombia is aware of proposing a social conscience about the own biodiversity, and must adopt a commoditization of tourism spots based on ecosystem sustainability, in order to increase productivity and social welfare (Ministerio de Ambiente y Desarrollo sostenible, 2014).

Historical footprints are represented by multicultural treasures on touristic destination namely: San Agustín and Tierradentro (at Huila and Cauca Regions) attracting great diversity of visitors. In this list of destination, we also include Sierra Nevada de Santa Marta as a destination nested at the top of the northern system of the mountains. The Ministry in charge of promoting tourism (Ministerio de Industria, Turismo y Comercio) recognized the huge richness of Colombia, regarding its intangible patrimony, artistic values in antique civilizations, the modern lifestyle and some traditional alive cultures.

A lot of own processes linked to national life bear out the benefit for the population derived from the enormous touristic potential that can carry additional benefits for the population as employment opportunities, increasing of income and strengthening the balance of payments (Mantilla V., 2016). In consequence, the public policy has tried to make up the touristic scheme, to reinforce the sectorial chain of value, and to evolve tourism from a general activity to an increasingly specialized one (Mantilla V., 2016). This approach endeavors to meet the expectations and desires of different kind of tourists, according to the motivation of visit. Some tourists deploy general activities related to leisure, and resting, while other visitors look for specialized services related to business, academic and scientific visits, cultural and focused on traditions purposes.

As a result, each human stratum projects its preference at every destination, reinforcing their decision for one safe environment as an opportunity to increase the wellbeing. So, design tourism could be used as a tool for cultural tool of exchanges across different people (Rozo \& Vélez, 2016), because in such activities come up human relationships apply expectations, expressions and social practices [...] for producing stories, human sharing and links (Rozo \& Vélez, 2016).

The sustainable tourism has been incorporated as a public policy in Colombian agenda some years ago. From times of "democratic security policy" some strategies have been deployed to mix safety and logistics to foster open mobility across diverse geographical points, through public-private partnership (Desarrollo turístico sostenible, 1999). Some specific measures proposed to promote and design tourism, which includes offering safety for visitors, development of financial instruments, improvement of touristic infrastructure and qualification of human capital (Roldán Luna, 2003) as means of attaining the development of tourism, the attraction of investment, the mobility of tourists and the promotion of local economies.

For operative procedures in this research, we use information extracted from the questionnaires completed by the tourists in situ. Processing questionnaires, we pose the interest on perception about safety in touristic destinations according to visitor's opinion. On the other hand, the Colombian statistical office (DANE), conduct a periodical survey assessing the perception of safety by tourists. Other private institutions analyzed the concrete situation of safety for Bogotá, the capital city, emphasizing the importance of continuous efforts to improve the security climate on the city.

Those urban analyses could be replicated at other scales and places with touristic potential, in order to project some paths of joint efforts between the public and private sectors, some educative institutions and civil society with the goal to prompt several activities with a diversified portfolio of touristic options all around the country. 
The historical limitations advocated by specific events were extremely different in each biological and environmental zone (Europe/America), discussing this aspect in Colombian Amazon Region takes a long journey to understand the locals interaction with their ways of living every day stuck in narco-traffic, and sharing experiences between outlaw groups (FARC, ELN) as (Trujillo Quintero, 2014):

"The presence of armed illegal groups and drug trafficking in the region forms a part of the recent history of the department Chocó or Colombian Amazon Region, but it comes to marking important guidelines as for conservation of ecosystems and capture of revenues."

Transporting this derogatoriness into touristic words, for many years was difficult to find a complete rural development in the zone occasioned by the "war zone" mentality not only taken for the state, but also department Chocó as Amazon Region natives that lived and suffered the harassment of armed illegal groups for almost 60 years (Palacio, 2008). This set of mind switch the lights of territory and culture concept (Ochoa Zuluaga, 2008) because nature was interconnected with territorial dispute and this brings on harmful and dangerous negative prejudices that even today make foreigners feel unsafe and untrustworthy when they visit reserves as Nukak or Puinawai (not only in Amazon Region, but also another parts of Colombia, e.g. department of Chocó), implicating them common stigmas associated with terrorism, gun control, kidnapping, murder and theft, as seen on another countries social media, newspapers and trend topics that are very present in strangers minds, when they visit the zone (Ojeda Revah, 2014).

Some proposals deal with the implementation of rural tourism, which acquires a particular importance; provided the new Colombian is peaceful with the countryside, afterwards the peace process was finished with guerrilla. Those kinds of projects can contribute to healing the society, to recovering the social capital, the promotion of productivity in lagged areas formerly affected by violence. This kind of tourism offers alternatives for rising incomes and welfare to reconcile the surrounding environment with Colombians and visitors.

Other kinds of touristic activities deal with direct visits to nature, defined according to (Organización Mundial del Turismo Madrid, 2003) as interaction with the natural environment to have the motivation, observation and engagement with the landscape, traditions, culture, including ecotourism, watching of birds and whales, agricultural tourism, adventure tourism, diving, and the previously mentioned rural tourism (Ministerio de comercio, industria y turismo, 2012). In Colombia, those experiences are ubiquitous because birds can be found at Orinoquía, whales at the Pacific Ocean and eco-tourism attraction at Guavio at the east of national capital. Adventure Tourism is strongly attractive to young people, and it is the particular specialty in some regions of the country; in consequence, several experts, institutions and organization have directed their attention towards analyzing some phenomena linked with the rating, rappel and hiking (López Bandera, 2015).

Another dimension in tourism that currently is growing among some visitors is the tourism by reasons of health, and emerges as an alternative for sectorial development, according to criteria of accessibility, cost-benefit, healthcare, etc. (Castro, Villarraga, Barreto, Victoria, \& Barbosa, 2011).

Activities surrounding religious tourism mix design and interest for analyzing the spiritual necessities of visitors, and the effect on local communities which find opportunities to recover the local life (Tobón Perilla \& Tobón Perilla, 2013).

Globalization offers a continuous environment, promoting the development of science and technology as opportunities for the intervention of stakeholders (Arias, 2016). 
Starting from this point, some people have proposed a productive and natural path, meaning the former has some experiences and knowledge, while the latter alludes to the interaction of the visitant with their natural surroundings (Revilla \& Moure, 2017).

Finally, we must highlight the historical legacy as a worthy heritage from the autochthonous and Hispanic past. Colombia keeps several traces from the pre-Colombian era, as an evidence of vast activities and scent of indigenous tribes namely: chibcha, caribean and muisca cultures. But also Hispanic settlement and conquest transmitted to posterity some urban, social and cultural insights, and afterwards, the Colombian independence era left several worthy monuments, institutions and structure, for the pleasure of contemporaneous population (GuerreroVargas \& Espinosa, 2017).

In conclusion, several aspects intervene for the sustaining of the country as an interesting exotic destination offering an infinite variety of opportunities in different sort of touristic activities. Although, the status of world-class touristic destination hinges on qualifying the tourism services and mobilizing capital and technology to isolated destinations. The country could exploit its comparative advantage expressed in several natural, historical and cultural attractions. Summing up the Colombian reality and expectations, we can quote the advertising campaign: the risk is to stay here willingly (visitcolombia, 2018).

\subsection{Description of destination: Bahía Solano}

We focused on the municipality of Bahía Solano, located in Chocó in the west strip of Colombia as an incipient tourism destination, and as a relevant experiment of local development based on tourism.

Figure 1. Colombia: regional GDP per capita (million of Colombian pesos)

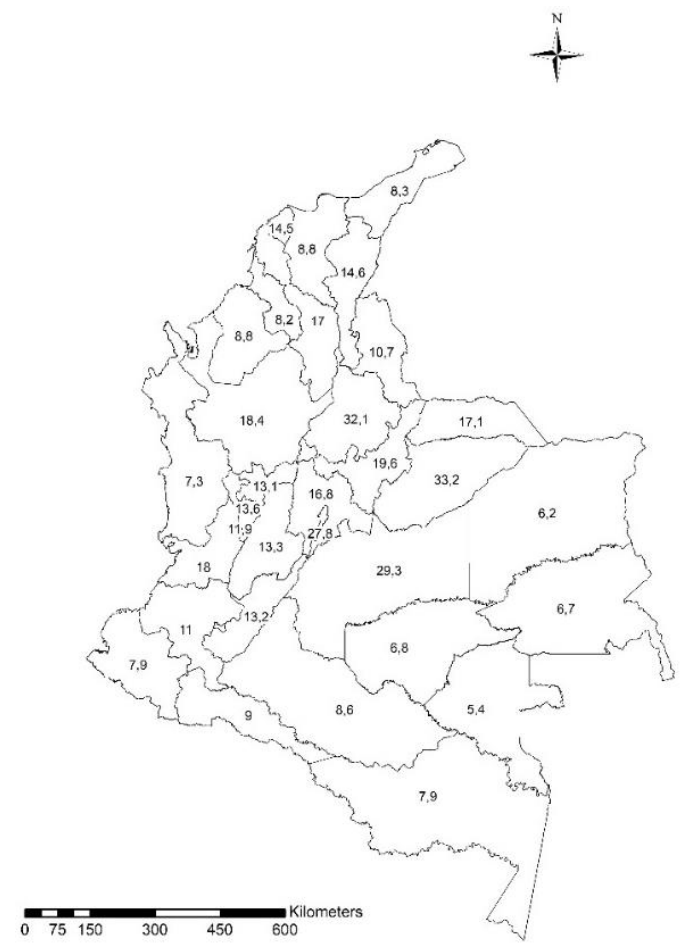

Source: Own elaboration on basis: IGAC and DANE. Department of Chocó GDP 7,3 (millions of Colombian pesos) 
The Colombian Pacific coast makes up a long fringe that expands by 1.300 kilometers and is composed of virgin jungle with high biodiversity and an enormous hydric richness. A variety of rivers cross throughout all the territory, giving a particular natural attractiveness, and carrying also abundant auriferous treasures. The region Chocó is the higher rainy area in Colombia, and the presence of hydric streams are abundant, to such an extent that Atrato River connects two oceans: the Pacific and the Caribbean. This fluvial body is used for daily communication across dispersed municipalities at the region of Chocó.

The Chocó, a western department in the Colombian Pacific coast, is an attractive place in terms of biodiversity and natural landscape; however, the economic and social reality shows a disappointing outcome. The region exhibits enormous lags in comparison to the rest of the country when several indicators of education, health and social coverage were evaluated. Moreover, the lack of connectivity relegates the whole region to the peripheries of the main country, and in some cases, the unique way to communicate the region is throughout the long journeys by river.

The municipality Bahía Solano is located in the west part of the Chocó's department; geographically, it is limited on the west with the Pacific Ocean, on the north part with Juradó, Carmen del Darién, on the south with Nuquí and on the east with Bojaya. The most economic area is recognized by fishing, agriculture, tourism and business (Mura, Kljucnikov, 2018). Bahía Solano has 9399 habitants, who were made up by three ethnic groups: black with African estate, indigenous with origin EmberaWounaan, mestizos (from mixture of race), and white settlers. The last one was established in this settlement, because it manages the public and private sector companies (Population City, 2018). Bahía Solano has got one hospital Julio Figueroa Villa with basic equipment (dentist, radiology, nurses and clinic laboratory with one director). In the village, El Valle is available to paramedics for the emergency help to move injured or indigenous people. The hospital and also emergency hasn't got any kind of transport for medical emergencies and any plan for disaster care. In general needs of administrative and economic improvement. In education, the major of the municipality has one preliminary school, two basic schools (one is only for indigenous) and one secondary school with afternoon lessons of education.

Bahía Solano, the case that appeals the group of scientists (Czech and Colombian) interest, has not overland connection with the interior of the country or even with their region. Transport communication is predominantly air or maritime. Bahía Solano has José Celestino Mutis airport that is 10 minutes from the center. The departure way is accessible only for low weights flights. To the center, the main places are possible to transport by taxi-moto service. To connect faster with destination, the common way to travel is by air, taking off from Medellín, the second largest city in Colombia or from Quibdó, the regional capital. The procurement of supplies for the town comes from the main port of Buenaventura, some kilometers south from Bahía Solano, in a longer travel arranged for people as well.

The town is made up of a beach stretched between sea and Baudó Mountains. Several activities were arranged by local people for enjoying leisure, namely: handcraft and sport fishing, culture of indigenous group of Embera in lagoon inspiration of idea of (Saptorini \& Viviani, 2018), design of diving (Viana, Halpern, \& Gaines, 2017), watching the migration of birds, spawning of turtles, promenades throughout the beach. The local population was made up of black and Indian inhabitants, and supplemented by inland people coming from other departments as Antioquia. 
The municipality of Bahía Solano lacks adequate infrastructure to develop artistic and cultural activities, shows severe deterioration in cultural patrimony. The local traditions are extinguishing and in consequence, the development level of artist expression is precarious. The artistic sector has several problems including a scarce institutional support, deficiencies in a number of teachers in topics like artistic formation and dance. To improve the actual infrastructure, it's necessary the participation of the Ministry of Culture, the regional government and the schools. Additional efforts can be done to promote the human wealth. One remarkable event organized by the foundation of 'Antonio Walter Mosquera' at the local level, is the festival 'Minga' aimed to reinforce the local culture. This festival is celebrated in Ciudad Mutis each year, from 10th to 13th of October, and that exposes the culture and folklore expressions of the Pacific coast.

Putting aside the reality of the region, the touristic potential is enormous. The beach at the Colombian Pacific Ocean has not been exploited commercially in a similar scale than the Caribbean Sea beaches. The touristic attraction in the research destination have been recently discovered, and in consequence, the infrastructure, the investment and the human capital mobilized are still relatively scarce. In spite of that, the Bahía Solano is a fully coastal municipality, there is not a port in stricto sensu, but there we find two jetties placed at the coast of Bahía Solano. In spite of that, the evident lack of development at the region, its fame as touristic place continues summoning tourist elsewhere.

Main tourism season depends on the migration of the animals. The season of watching turtles is during July and November, watching whales from July to September, watching birds from September to January and dolphins could be seen during the whole year.

In concrete, the municipality of Bahía Solano offers a diversity of potentialities for all kind of visitors, and the activities range from natural beaches, excursion by rivers and ultimately, the spotting of humpbacks whales as an exotic and amazing activity that precisely in the respective season is a unique and exceptional spectacle.

The whale migration each year comes up from a natural phenomenon that is a feature in the behavior of such animals. During this season, whales move from the Antarctic and the south of Chile looking for warm waters and places to mate and birth, and in doing so, they finish their journey at the Colombian Pacific. This natural phenomenon becomes a stunning spectacle for animals admirers and nature lovers, in consideration to the scarce places where the spectacle can be found. The back of whales can be appreciated on the surface of the sea, and on lucky occasions, some animals can be seen jumping above the water.

This enormous mammal can't pass unnoticed, because of their dimensions. The length of its body can reach 30 meters, while the weight can rise to 40 tons.

A typical season for whales watching runs from July till September, driving the economic terms into a seasonal activity submitted to economic cycles of expansion in touristic services. It means that the specific activity of watching whales predominates during the second part of the year, while other attraction must be exploited during the first part of the year.

The watching of whales is an activity linked to foreign visitors and also to some Colombian tourism, but other attractions fill the schedule of tourist during the beginning of the year, the holy week and the eastern.

But Bahía Solano is not the only Colombian place susceptible to receiving visitors. Other places are the Nuquí and the Bahía Málaga, the latest place that enjoys longer season due to its more southern position. But not only has the spectacle of whales invited 
people to come. The region is the natural habitat of several animal species, like marine turtles also attractive for nature lovers.

Several types of tourism arose in the region (República de Colombia Ministerio de Trabajo, 2013). The more exploited modality is the ecologic supported by the natural landscape and the geographical position of the region. This item involves exploitation of beaches, forest, etc. Other kinds of activities of the design process are related to ethnic tourism, design of ecotourism (Eshoo, Johnson, Duangdala, \& Hansel, 2018), forest design tourism (Mahmoudi, Sharifi, Ahmadian, Sepasi, \& Danehkar, 2012) and adventure tourism (Ballantyne, Packer, \& Sutherland, 2011). The natural resources in designing activities also need special preservation and respect in the first step, so every strategy could be designed with special care for the environment.

\section{Methods}

The on-ground operative of collecting information by means of questionnaires was performed by the research group belonging to the Scientific Park of Social Innovation (PCIS) of Minuto de Dios University in Bogotá and University the College of business in Prague. For operative, stage two operative of data collection was held during high season in 2017 and 2018. Semi-standardized questionnaires (Richards and Munsters, 2010) were modified with 32 questions, and were applied to foreign and Colombian tourist visiting diverse attraction in Bahía Solano municipality. Questions were aimed at nature interpretation, sun and beach, whales, tourism-cultural, ethnic, scientific, agro-tourism, sighting birds, diving, surfing, artisanal fishing, and cruise and river navigation. In the first stage, the ground research was provided with pilot questionnaires, and in the second stage, questions were modified according to the needs of the destination, and also according to the profile of the tourists. In 2017 in pilot project Czech and Colombian researchers validated 62 questionnaires, and 66 were applied in 2018 in order to capture the assessment of visitors' experience and perception during their journey to the zone. The whole size of the sample was performed by questionnaires with 41 men and 25 women. The respondents were scaled by $18-30$ age (34\%) and $31-50$ age (55\%) and $10 \%$ more than 50 age.

Afterward, the qualitative exploratory study is presented with proceeded basic data in statistical program SPSS. In this case for design tourism planning in Bahía Solano in order to cross the behavior of nominal variables, and to reduce dimensions were applied Optimal scaling tool, a multivariate procedure generally contained in statistical software. For the confidence of inner consistence using Cronbach's Alpha (Greenacre, 2007) that is based on the average of common correlation between the items. The final results are presented in symmetrical correspondence maps built in two dimensional axes that arrange the variables and attributes, putting on closer more related categories.

Providing that optimal scaling contributes to make up robust profiles of the visitors according to their preferences, in consideration to the like and dislike perception of the destination, and the strengths and weaknesses according to their comments found in the observed tourism destination. That could be used for the subsequent designing of the Plan of Tourism in Bahía Solano. 


\section{Results}

The results design each correspondence map subsequently, in order to highlight several features associated with diverse description of visitors and tourism activities. These statistical procedures align points applying distance criteria according to the closeness in the relationship between variables and categories. The final results are summarized in four models (Table 1), where diverse variables were analysed.

Table 1. Models of optimal scaling

\begin{tabular}{|c|c|c|c|c|c|}
\hline \multirow[b]{2}{*}{ Model } & \multirow[b]{2}{*}{ Variables } & \multirow[b]{2}{*}{$\begin{array}{l}\text { Cronbach's } \\
\text { Alpha }\end{array}$} & \multicolumn{3}{|c|}{ Variance accounted for } \\
\hline & & & $\begin{array}{c}\text { Total } \\
\text { (Eigenvalue) }\end{array}$ & Inertia & $\begin{array}{l}\% \text { total of } \\
\text { variance }\end{array}$ \\
\hline 1 & $\begin{array}{l}\text { country of origin, budget, } \\
\text { tourism activity, civil status }\end{array}$ &, $652 \mathrm{a}$ & 1,958 &, 489 & 48,944 \\
\hline 2 & $\begin{array}{l}\text { country of origin, like and } \\
\text { dislike region }\end{array}$ & ,733a & 1,955 & ,652 & 65,177 \\
\hline 3 & $\begin{array}{l}\text { country of origin, like and } \\
\text { dislike destination }\end{array}$ & ,637a & 1,738 & ,579 & 57,943 \\
\hline 4 & $\begin{array}{l}\text { age of visitors, sense of } \\
\text { safety, reasons of safety and } \\
\text { tourism activity, civil status }\end{array}$ & ,664a & 2,239 & ,337 & 37,320 \\
\hline
\end{tabular}

Source: own elaboration.

The largest number of visitors in Bahía Solano destination come from Colombia (72), and the second most come from Germany (17). Although, it isn't surprising that several foreigners arrive to Bahía Solano, while some particular visitors decided to stay in the region for a long time. The department of Chocó hasn't got a long tradition as a tourist destination in comparison with largely exploited destinations such as Cartagena and the Atlantic Coast, San Andrés Islands or the inland zones of the whole country. In spite of the isolation of the Choco offshore, the knowledge of the department is transmitted in the international context. Regarding the department Choco and municipality Bahía Solano, carrying out lagged destinations into international fairs is expensive. Therefore, it's possible integrate such places into a national effort of international promotion (Mura, 2019), in order to support the cost (Organización Mundial del Turismo (Madrid, 2003).

During the ground research in Bahía Solano, we questioned visitors coming from diverse countries. Most of them were from Latin America (in total 72 from Colombia, Argentina (4), Chile (3), Ecuador (2) and 1 from Peru), but others proceeded from Europe (in total 17 from Germany, Spain 7, France 5, Italy 4, UK 4, Belgium 2 and Czech Republic 1) and even from North America (in total 6 from USA and 1 from Canada) and Australia (1). Colombian people are more accustomed to hearing about national destination. The general information about whales movements is highly extended as a general national knowledge. The Colombian people also evaluate highly the coastal landscape such as scenery for holidays and short journeys, despite the large part of the national tourism masses are attracted by the northern Atlantic Ocean Coast.

International visitors assume the Chocó department as an exotic destination animated by whales, natural landscape and sea activities. In this survey was detected that foreign people recognized the Bahía Solano mainly from Colombia, and very few cases 
of American visitors from Lonely planet. In both surveys (2017 and 2018) greater number of Latin American visitors were found.

According to the criterion of Cronbach's Alpha, we have chosen three models (model 1,2 and model 4) for the conclusions and for designing the process of planning tourism in Bahía Solano. In the model 2 is explained by the first dimension $64 \%$ of variance, and in the second dimension $62 \%$ of variance is explained. In consequence, both dimensions were explained $126 \%$ of total inertia, which indicates a quality of resolution. In the model 4 is assumed the confidence closer to 0,7 of Cronbach's Alpha. The model was interpreted for an observation of visitors budgetary to travel to Bahía Solano.

Observing the interaction between country of origin and tourism activities, Colombian tourists are surrounded by a higher diversity of activities in Bahía Solano destination. It means that obviously by the general information, national visitors are more aware of local beauty. The interests of international visitors are more dispersed. The Belgians, French and British had a more interest in tourism activities like river navigation and nature interpretation. The North Americans are mostly interested in sighting whales.

Figure 2. Correspondence map of the model 1 - country of origin visitors, budget (in thousand Colombian pesos) and tourism activity and civil status ${ }^{1}$

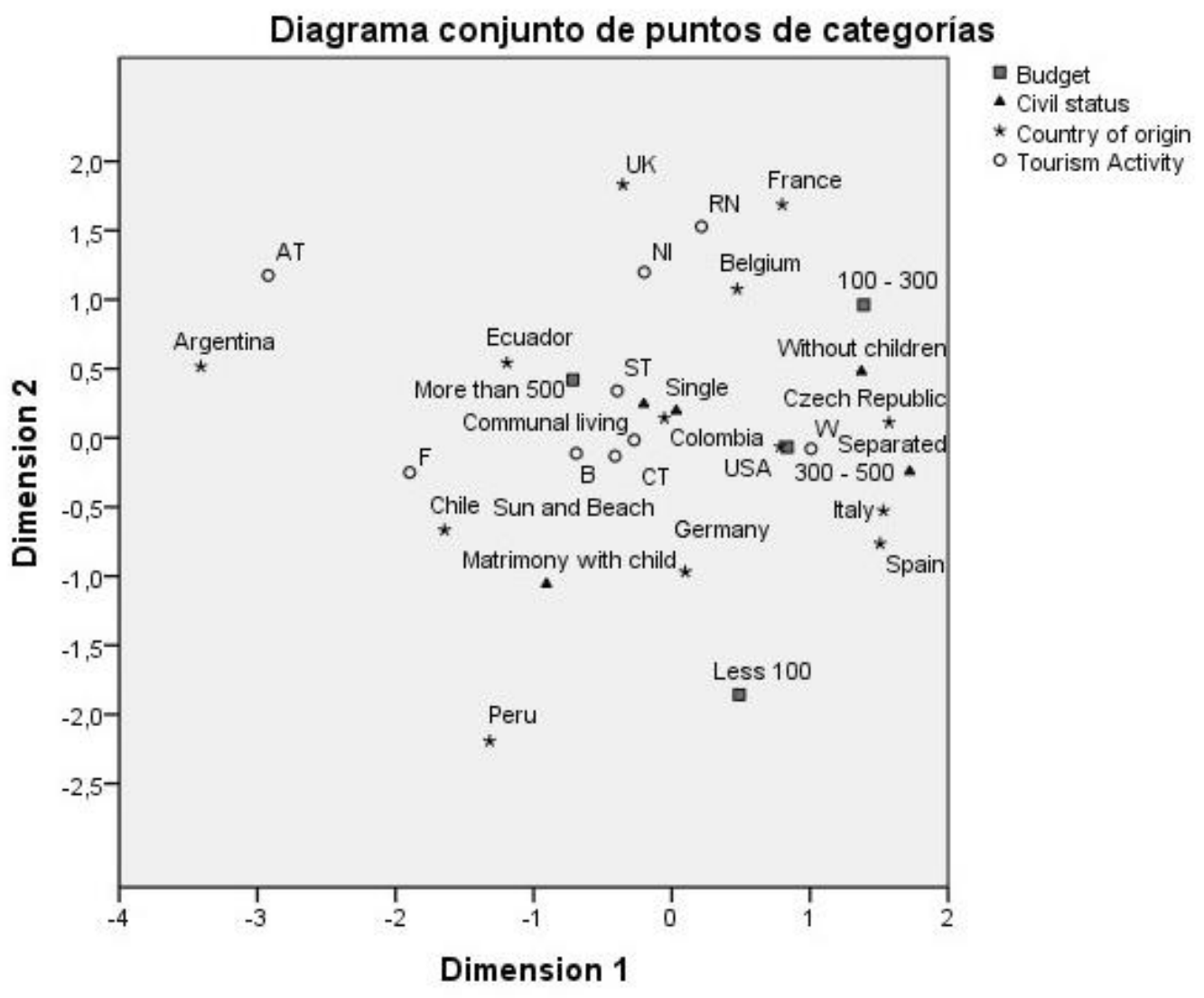

Normalización simétrica.

Source: Own elaboration

1 NOTE: AT - agro tourism, B - sighting birds, CT - cultural tourism, F - fishing, NI - natural interpretation, RN - river navigation, ST -Scientific tourism, UK - United Kingdom, W - whales 
The greater segment of Colombian visits to the Bahía Solano had more variable budget than foreign visitors. The foreigners tend to spend less money in Bahía Solano, because they expect to also distribute another part of the budget into the diverse Colombian destinations:

Table 2. The expenditure of visitors in Bahía Solano

\begin{tabular}{|l|l|}
\hline Category of the budget in thousand COP & Frequency \\
\hline Less 100 & 22 \\
\hline $100-300$ & 14 \\
\hline $300-500$ & 23 \\
\hline More than $500^{\mathrm{a}}$ & 69 \\
\hline
\end{tabular}

Source: Own elaboration

Even for national and foreign visitors, the best experiences are associated with natural "milieu" that surrounds the Bahía Solano location. The design plan according to the design experience of tourism could propose to vary from activities (Xiang \& Fesenmaier, 2017). On the other hand, visitors expect tourism services to be aligned with each other, and to contribute to the overall destination experience. Therefore, the design of the new experience services (Gardiner \& Scott, 2018) becomes a problematic aspect of a design development process aiming at experience-centric services (Fesenmaier \& Xiang, 2017).

Figure 3. Correspondence map of the model 2 - country of origin visitors, perception of like and dislike region

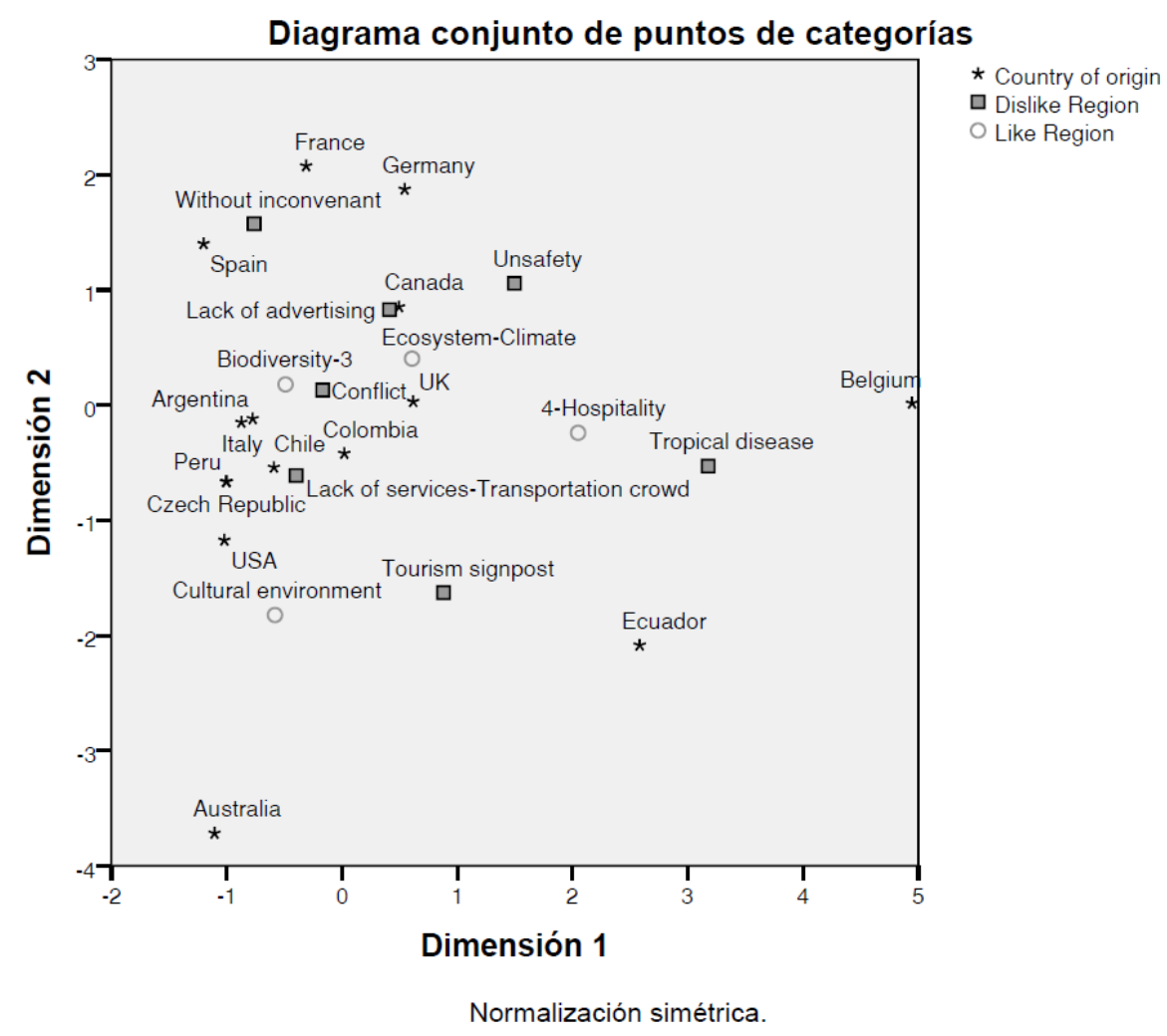

Source: Own elaboration

Negative general perception of visitors is related to the insufficient tourism infrastructure in the Bahía Solano municipality and the lack of some basic services, such 
as trash recollection and precarious access routes. On the other hand, British visitors perceived the lack of advertising and the tourism signpost in the whole department of Chocó. The most segmented tourists (Germany, Argentina, Czech Republic and Canada) mentioned the inconvenient in the perception of conflict in the department. Maybe it could be for the presence of the military, who take control of the crime in these destinations. Although, the same groups of visitors appreciate the amazing biodiversity of the Colombian places. But in spite of the negative perception by the tourist, they wish to find better conditions in future visits (especially in the tourism services and also in sufficient basic equipment to overcome the unstable ecosystem-climate). In those terms, the tourists are interested in improving the reality of concrete tourism offer. The designing plan of tourism for Bahía Solano could promote the route customization (Zheng, Liao, \& Qin, 2017) and design services (Sánchez-Zárate, 2016), which can offer more realistic and personally satisfying activities according to the positive expectation of the visitors. So, tourism could be provided with synergies (Rivera, 2017) of poverty reduction, and should be noticed about the promotion of opportunities which can give rise the wellbeing of the surrounding population (Jamieson et al., 2004).

Figure 4. Correspondence map of the model 4 - tourism activity, age and civil status of visitors, country of origin, safety in Bahía Solano and safety reasons ${ }^{2}$

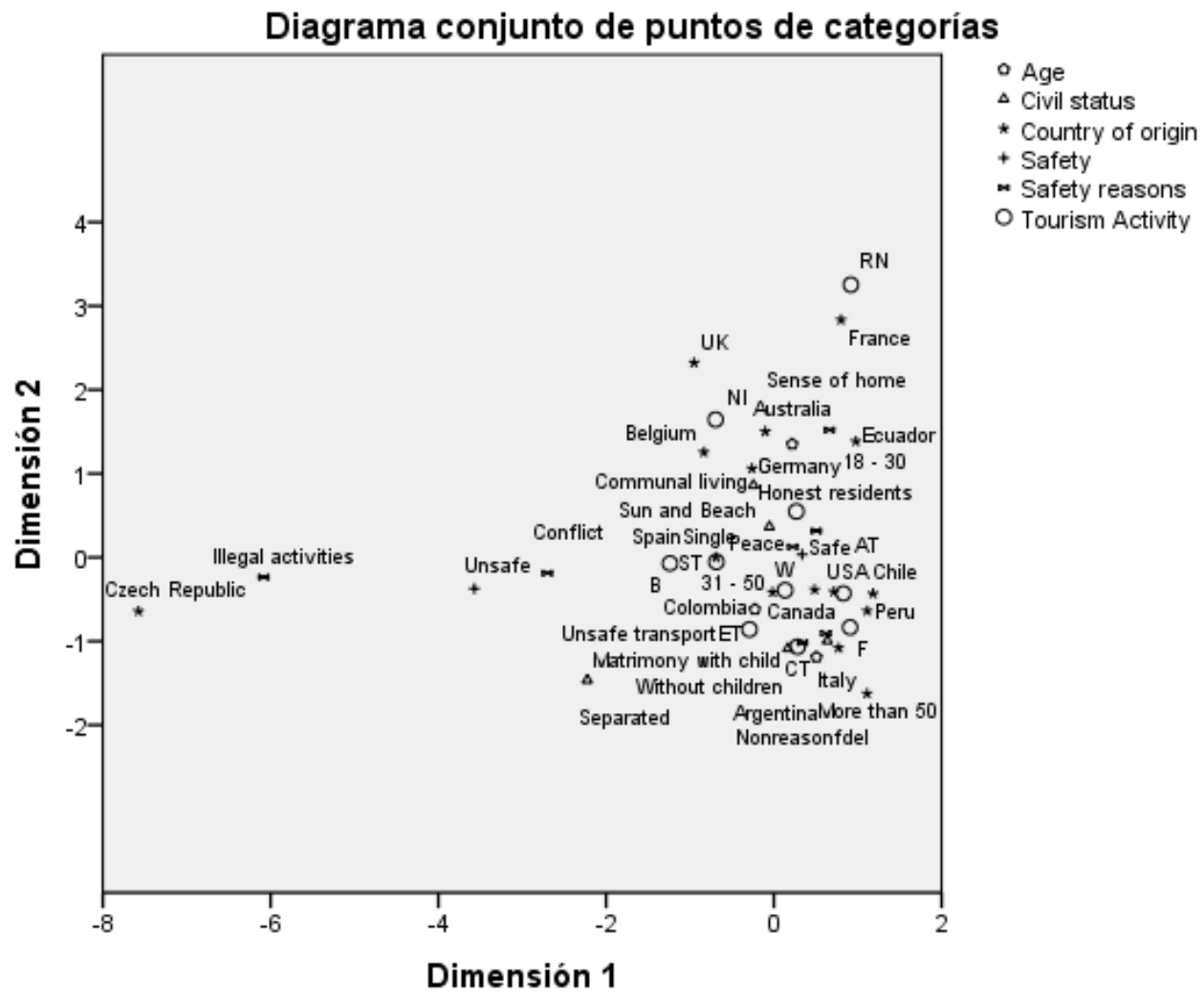

Normalización simétrica.

Source: Own elaboration

2 NOTE: AT -agro tourism, B - sighting birds, CT - cultural tourism, F - fishing, NI - natural interpretation, RN - river navigation, ST -Scientific tourism, UK - United Kingdom, W - whales, ET ethnic tourism 
Observing the civil status, there is no clear pattern of preference for any particular activity, perhaps the diversity of attraction existing in the destination is preferred by all tourists profiles.

Table 3. The civil status of visitors in Bahía Solano

\begin{tabular}{|l|l|}
\hline Civil status & Frequency \\
\hline Single $^{\mathrm{a}}$ & 59 \\
\hline Communal living & 27 \\
\hline Matrimony with children & 24 \\
\hline Without children & 16 \\
\hline Separated & 2 \\
\hline
\end{tabular}

Source: Own elaboration

The destination attracts visitors in all ranges of age, but we suppose that younger people are more prone to perform risky activities (sighting whales and agro-tourism). The younger tourists were from Australia, Germany, Belgium and Ecuador, and they perceived a special attendance in place of Bahía Solano like the sense of home during their stage on sun and beach. The honest residents provided a peaceful environment, which is appreciated by a huge range of tourism segment (Latin and North Americans, Spanish) who are singles or living in matrimony without children. Spanish tourists preferred a scientific tourism more than sighting birds. Italians and Argentinians over 50 years old travelled in matrimony with children to exert cultural tourism. Peruvians and Chileans practiced artisanal fishing, perhaps by traditional customs from their origin; unfortunately, with the perception of unsafe transport. As a corollary, figuring out the profile of the visitors could contribute to several aspects in the management of local tourism. First, it could guide the advertising strategies to attract convenient visitors into Bahía Solano destination. Second, specific preferences of any kind of tourists could contribute to enhancing the special supply of services offered by local agents.

\section{Discussion}

Tourism is a paramount tool to boost regional development, provided its capacity to generate employment in an amazing spot is surrounded by sun and beach, ecology, adventure and unique landscapes. Specifically, the municipality of Bahía Solano has been endowed with appealing tourism attractions, such as the sighting of whales (particularly since July till October), dolphins and birds. Other remarkable spots are the National Natural park of Utría, forest tracks, waterfalls, significate natural depressions, rivers and rivulet, natural pools and thermal waters, along with several virgin places suitable for sports activities.

Other diverse activities can be practiced namely: artisan fishing, diving with the tank in reef zones and exploring sunk ships, promenades to tracks into forests and rivers, sightings of waterfalls in a forest and at the coast, sightings of birds and butterflies and promenades through the sand.

Some specific local spots suitable for tourism supply are: El Valle, Playa Solano, Playa Juna, Tebada, Potes, Cascada del Rio Chado, Punta Huina, Bahia Cupica, Nabuga, El Almejal, Cocacola, Paridera, los Vidales, Cascada el Tigre and Salto Chocolatal. 


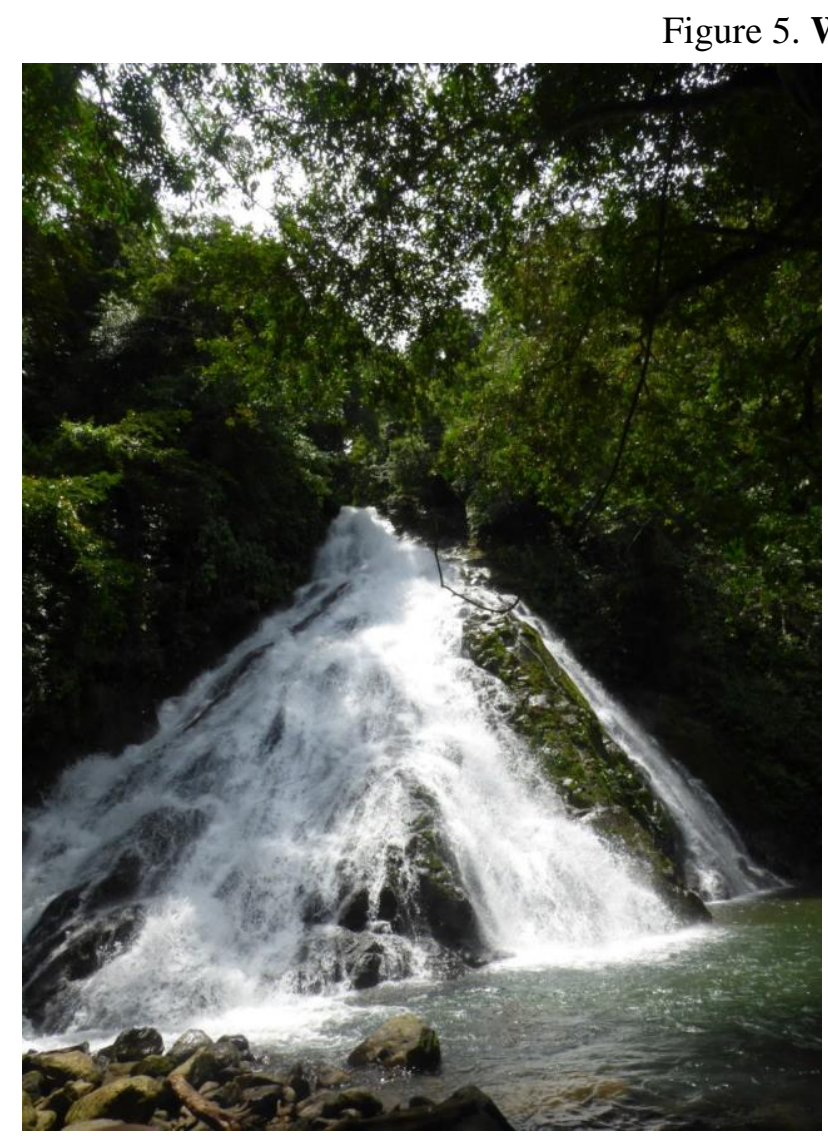

Source: Own elaboration

Marine endowments facilitate diving activities, fishing, surfing and the remaining aquatic sports. Although, the huge natural patrimony has a relevant feature in Bahia Solano, it maintains a dramatic social underdevelopment, high poverty level and in terms of productive structure, the tourism sector still lacks competitiveness.

Several drawbacks also affect its economic performance. The municipality lacks public policy for tourism promotion, and plan for tourism development. The infrastructure is really deficient, and existing facilities such as a small airport, jetties, urban amenities, roads are really lagged. Urban roads are not paved; therefore, during the rainy season, the streets become full of mud. Isolation is reinforced by lack of communications, and the virtual connection to the internet is really scarce. Health and sanitation are deficient, due to the absence of trash and residuals handling, the health services are barely supplied with scarce procurements.

Air transportation is irregular and expensive, worsened by the deficient conditions in the incipient local airport. Prices of sea transportation are not regulated, and could suffer volatility. In spite of the enormous natural potential, the local population lacks adequate attitude towards tourism services, because such activities have not been rooted into local society and local economic groups such as hotels, restaurants, agencies and so on, has not convergent interest in developing tourism activities.

From the particularities and tools of service design, it is possible to see that, in a context of socially responsible, design and designer can exert a great influence focused too on social, local and environmental innovation. Service design can also help indigenous people to transform processes, which can vary, if participatory design methods are adopted. The idea is to involucrate indigenous communities in the redesign 
of the services in co-creating consequence solutions, and this implies "developing capacities" so that people participate in the said processes in a conscious and committed way. One possibility for this thought is based on the ideas of Meroni \& Sangiorgi (2011), is the creation of prototypes of services (for example, in the field of ethno tourism), or the design of platforms that allow collaborations in the service. And, in the case of indigenous communities, there is the possibility of co-designing services (Meroni \& Sangiorgi, 2011) among experts and indigenous people.

Torralba (2015) indicates that the search for a harmonious relationship between culture and tourism is a complex task, since the two rationalities are often faced with the market that seeks profitability in a short-term, and the cultural one, concerned with the defense of values collectives of public dimension. Once these two criteria are unified, some recommendations could be posed to improve the efficiency of product design and conservation cultures (Allauca \& Altamirano, 2015).

The abundance of the resources and tourist attractions, as well as the wide range of tourist services, require a characterization and evaluation of them with the purpose of determination, at the time of the product design; how to elaborate the mixtures of elements with the purpose to give individuality to a product like creative integration strategies (Volgger, Herntrei, Pechlaner, \& Pichler, 2018), define type, innovative products, and determine the ranges of sale prices to the public or select the means of promotion and distribution channels.

The characterization is a process that aims to determine precisely the nature of an element, the way of being of a human group or the style and originality of a gastronomic establishment or accommodation. The purpose is to have arguments to support its inclusion at the time of product design.

However, they can be useful in discussions conducted by professionals and aimed at the exchange of information, as well as in the process of designing strategies for operations focused on the promotion of tourism.

\section{Conclusion}

The inclusion of the poor as beneficiary of the touristic activities is a multidimensional effort. Punctual social investment is insufficient if it doesn't impel economic growth. So, a sustainable strategy for alleviating poverty in touristic regions is to integrate the poor people in the market circuits that guarantee a permanent and secure livelihood for them. One important step is also motivation (Pérez-Gálvez, Torres León, Muñoz-Fernández, \& López-Guzmán, 2018) to design process of indigenous people, which could be primordial access to the development of Bahía Solano. The participatory community development model (Tosun, 2005) could lead the tourism and the design of activities. This strategy could be supplemented with additional general efforts to qualify the local touristic product.

The indigenous people in focus destination were surprised by large flows of tourist for enjoying huge natural beauty; however, some strong effects were transmitted to the local environment, which disturbed the daily life of inhabitants, and can put at the risk of environmental equilibrium.

As an emerging poor destination, we find several drawbacks in social and economic local structure. We detected the local institutional deficiencies to handle the tourism boom and general lack of developed infrastructure for underpinning stable tourism growth. From the public policy point of view, huge efforts must be implemented: 
effective integration with the whole country, the redistribution of tourism rents in favor of local inhabitants, preservation of natural environment amid whales and sea (Kessler, Harcourt, \& Bradford, 2014), and a progressive local taxation development.

Several principles must guide the regional promotion of stable economic activities. All benefits derived from the tourism development must be driven by the local population, and people must participate as an agent of development. Flows of visitors must be consistent with the local capacity to receive them, consistently with the environmental and physical constraints.

The spontaneous process of tourism development can challenge any effort of planning territory and mismanaged expansion of economic activities can put on the risk of precarious local environmental equilibrium. So, the public policy must reinforce the institutional framework, rearranging priorities for the sake of promoting sustainable tourism activities. In conclusion, we can summarize that in Bahía Solano area, the redesigning and rebranding of the image of the destination is a key component (Moore, 2015) for the success of tourism development as for a life quality of indigenous people.

This article extracted information arising from visitor's perception about safety and general conditions prevailing amid Bahía Solano. The collected information about personal and sociological features belonging to visitors. With such information, we were allowed to build some generalities and profiles regarding national and international visitors.

Several deficiencies open up by the tourists' perceptions to expose local realities. Deficiencies indisposition of trash, in particular, the plastics cast into the sea, access roads and inland streets must be paved for and accommodation conditions must be improved. We propose for Bahía Solano accommodation design to be accessed as a green hotel (Brody, 2014) or bed\&breakfast with environmentally friendly facilities (e.g. Hostal del mar). A remarkable comment coming from the visitors highlights the lack of advertising information in the destination, as well as outside the regional context, so huge efforts for promoting destination (Bassols, 2016) must be integrated into the national and international advertising campaigns. The improving of design of web pages (Lira Rivas, Rivera Rocha, \& Toruño Pérez, 2017; Luna-Nevarez \& Hyman, 2012) it could help also to promote the destination. Another proposal that should be helpful for more information is to locate the maps points, and orientates the tourists on the departure point of the airport in Bahía Solano. The tourists' agents also could designed the information point on the airport with tourists welcome package (designed catalogues of tourist products Bahía Solano) about indigenous people activities in the most tourist places of Bahía Solano with orientation maps and products catalogues (Mikos vs. Rohrscheidt, 2008). On groundwork showed an important presence of foreign visitors amid the local population, that requires the improvement of languages skills of tourism agents. In addition, the foreign visitor tends to be tougher by asking for quality in accommodation and tourism infrastructure.

Regarding the profile of the visitors that could be made up, some comments can be expressed. Colombian visitors tend to spend more money in Bahía Solano than foreigners do because foreign people must distribute their budget between more journeys within Colombia. Natural sites visitors and policymakers can also be designed for tourism strategies (Ercolano, Gaeta, \& Parenti, 2018).

It means that local tourism suppliers could improve and enhance the quality of services and diversify attraction. A wider and better supply of services could invite the foreigner to spend more money because higher budget visitors can afford additional aggregate values in tourism services under the condition of getting a more comfortable journey, and more intensive experience. 
As exposed in the theoretical background, the qualification of supply and diversification of tourism services contributes to increasing the local aggregate value. Concomitant, positive local effects can be maximized to the extent that the indigenous agents were involved in new services generation, creating wealth and reducing outward leakages. The conclusions from the Optimal scaling could be used as input to promote tourism in Bahía Solano and could contribute to targeting public campaigns according to the profile of the visitors coming from diverse countries. These results are used for updating the Bahía Solano Tourism Development Plan.

\section{Acknowledgement:}

We thank Major Harley Liliana Ortiz Salazar and her entire team, for their unwavering support. We are also very grateful to Parque Científico e Innovación Social in Bogotá for the collaboration of the process, especially to the coordinator of the project, Mauricio Peralta Mejía, Cindy Lamprea and the researcher, Ivan Dario Medina from the Faculty of management Corporación Universitaria Minuto de Dios.

\section{Grant funding:}

Corporación Universitaria Minuto de Dios. Bogotá. General Directorate of Investigations. Through the third internal call for the research projects, for the support of interdisciplinary and inter-institutional research 2017 and for the support of Major of Bahía Solano.

\section{References}

1. Allauca, M. P. B., \& Altamirano, T. D. M. (2015). El etnoturismo y las dificultades en su desarrollo. Revista Publicando, 2(5), 243-255.

2. Arias, J. (2016). Innovación Social, concepto ligado a la praxis; caso Parque Científico de Innovación Social de UNIMINUTO - Colombia. In Innovación Social en Latinoamérica. Retrieved from http://www.uniminuto.edu/documents/1242125/7107898/Innovaci\%C3\%B3nSo cial_Latinoamerica.pdf/18b5de7a-0ae8-4aa0-be18-a3c22d4762e1?version=1.0

3. Ashley, C., Boyd, C., \& Goodwin, H. (2016). Pro-poor tourism: Putting poverty at the heart of the tourism agenda | Overseas Development Institute (ODI). Retrieved September 8, 2018, from ODI Evidence, ideas, change website: https://www.odi.org/publications/2096-pro-poor-tourism-putting-poverty-atheart-tourism-agenda

4. Bahía Solano. (2016). Bahía Solano cambiando para mejorar, 106.

5. Ballantyne, R., Packer, J., \& Sutherland, L. A. (2011). Visitors' memories of wildlife tourism: Implications for the design of powerful interpretive experiences. Tourism Management, 32(4), 770-779. https://doi.org/10.1016/j.tourman.2010.06.012

6. Bassols, N. (2016). Branding and promoting a country amidst a long-term conflict: The case of Colombia. Journal of Destination Marketing \& Management, 5(4), 314-324. https://doi.org/10.1016/j.jdmm.2016.10.001

7. Blake, A., Arbache, J., Sinclair, T., \& Teles, V. (2010). Tourism and poverty relief (Textos Para Discussão No. 237). Retrieved from FGV/EESP - Escola de 
Economia de São Paulo, Getulio Vargas Foundation (Brazil) website: https://econpapers.repec.org/paper/fgveesptd/237.htm

8. Brody, D. (2014). Go Green: Hotels, Design, and the Sustainability Paradox. Design Issues, 30(3), 5-15. https://doi.org/10.1162/DESI_a_00274

9. Çakmak, E., \& Isaac, R. K. (2016). Drawing tourism to conflict-ridden destinations. Journal of Destination Marketing \& Management, 5(4), 291-293. https://doi.org/10.1016/j.jdmm.2016.10.004

10. Castro, A. M. B., Villarraga, M. L. F., Barreto, Á. L. R., Victoria, A. J. S., \& Barbosa, W. G. J. (2011). Turismo en salud: una tendencia mundial que se abre paso en Colombia. Ciencia y Tecnología Para La Salud Visual y Ocular, 9(1), 125-137. https://doi.org/10.19052/sv.226

11. Desarrollo turístico sostenible: guía para las Administraciones locales: una publicación de turismo y medioambiente. (1999). Madrid: Organización Mundial del Turismo.

12. Ercolano, S., Gaeta, G. L., \& Parenti, B. (2018). Pompeii dilemma: A motivationbased analysis of tourists' preference for "superstar" archaeological attractors or less renowned archaeological sites in the Vesuvius area. International Journal of Tourism Research, 20(3), 345-354. https://doi.org/10.1002/jtr.2186

13. Escobar, A. (2018). Designs for the Pluriverse: Radical Interdependence, Autonomy, and the Making of Worlds. Durham: Duke University Press Books.

14. Eshoo, P. F., Johnson, A., Duangdala, S., \& Hansel, T. (2018). Design, monitoring and evaluation of a direct payments approach for an ecotourism strategy to reduce illegal hunting and trade of wildlife in Lao PDR. PLOS ONE, 13(2), e0186133. https://doi.org/10.1371/journal.pone.0186133

15. Fesenmaier, D. R., \& Xiang, Z. (Eds.). (2017). Design Science in Tourism. https://doi.org/10.1007/978-3-319-42773-7

16. Gardiner, S., \& Scott, N. (2018). Destination Innovation Matrix: A framework for new tourism experience and market development. Journal of Destination Marketing \& Management, $10, \quad 122-131$. https://doi.org/10.1016/j.jdmm.2018.07.002

17. Gómez, H. Y. A., \& Antošová, G. (2014). Tourist's Perceptions in the Liberec Region. Czech Journal of Tourism, 3(1). https://doi.org/10.2478/cjot-2014-0003

18. Greenacre, M. J. (2007). Correspondence analysis in practice (2nd ed). Boca Raton: Chapman \& Hall/CRC.

19. GuerreroVargas, J. J., \& Espinosa, J. (2017). Norte de Santander, Colombia. Turismo histórico-cultural, naturaleza y aventura: apuesta estratégica para la proyección departamental en el posconflicto. International journal of scientific management and tourism, 3(1), 145-175.

20. Holland, J., Burian, M., \& Dixey, L. (2003). Tourism in poor rural areas: diversifying the product and expanding the benefits in rural Uganda and the Czech Republic.

21. ILO International labor office. (2018). Poverty reduction through tourism. Retrieved September 8, 2018, from http://www.ilo.org/wcmsp5/groups/public/--ed_dialogue/---sector/documents/instructionalmaterial/wcms_162289.pdf

22. Jamieson, W., Goodwin, H., \& Edmunds, C. (2004). CONTRIBUTION OF TOURISM TO POVERTY ALLEVIATION. 38.

23. Kessler, E., Harcourt, R., \& Bradford, W. (2014). Will Whale Watchers Sacrifice Personal Experience to Minimize Harm to Whales? Tourism in Marine 
Environments,

$10(1)$,

$21-30$.

https://doi.org/10.3727/154427314X14056884441662

24. Lira Rivas, E. A., Rivera Rocha, J. C., \& Toruño Pérez, I. E. (2017). "Propuesta de promoción, comercialización y elaboración de un paquete turístico para la comunidad Icalupe, Somoto-Madriz, durante el II Semestre 2016" (Other, FAREM-Estelí). Retrieved from http://repositorio.unan.edu.ni/3723/

25. López Bandera, H. (2015). Normativa aplicable al Turismo de Aventura y a las entidades competentes de los niveles nacional, departamental, distrital y municipal de Colombia. Retrieved September 15, 2018, from http://www.mincit.gov.co/minturismo/loader.php?IServicio=Documentos\&lFun cion=verPdf\&id=77661\&name=CARTILLA_WEB_Acopio_Normatividad_Tur ismo_de_Aventura.pdf\&prefijo=file

26. Luna-Nevarez, C., \& Hyman, M. R. (2012). Common practices in destination website design. Journal of Destination Marketing \& Management, 1(1), 94-106. https://doi.org/10.1016/j.jdmm.2012.08.002

27. Mahmoudi, B., Sharifi, N., Ahmadian, R., Sepasi, Y., \& Danehkar, A. (2012). Planning of Rural Ecomuseums in Forest Rurals in Mazandaran Province, Iran. Journal of Management and Sustainability, 2(2). https://doi.org/10.5539/jms.v2n2p241

28. Mantilla V., S. (Ed.). (2016). Desarrollo y turismo sostenible en el Caribe (Primera edición). Bogotá, D. C: Universidad Nacional de Colombia.

29. Meroni, A., \& Sangiorgi, D. (2011). Design for Services (1 edition). Burlington, VT: Routledge.

30. Mikos vs. Rohrscheidt, A. (2008). Cultural Tourism - concerning the definition. Turystyka Kulturowa, 17.

31. Ministerio de Ambiente y Desarrollo sostenible. (2014). V informe nacional de Biodiversidad de Colombia, ante el convenio de diversidad biológica. Retrieved October 8, 2019, from http://www.co.undp.org/content/dam/colombia/docs/MedioAmbiente/undp-coinformebiodiversidad-2014.pdf

32. Ministerio de comercio, industria y turismo. (2012). Política de turismo de naturaleza.

33. Mittermeier, R. A., Elizondo, R., Goettshc Mittermeier, C., Robles Gil, P., Segovia, T., Wilson, E. O., CEMEX. (1997). Megadiversidad: los países biológicamente mas ricos del mundo. México: Agrupación Sierra Madre.

34. Moore, A. (2015). Islands of Difference: Design, Urbanism, and Sustainable Tourism in the Anthropocene Caribbean: Design, Urbanism, and Sustainable Tourism in the Anthropocene Caribbean. The Journal of Latin American and Caribbean Anthropology, 20(3), 513-532. https://doi.org/10.1111/jlca.12170

35. Mura, L., Kljucnikov, A. (2018). Small Businesses in Rural Tourism and Agrotourism: Study from Slovakia. Economics \& Sociology, 11 (3), 286-300. https://doi.org/10.14254/2071-789X.2018/11-3/17

36. Mura, L. (2019). Entrepreneurship internationalization - Case of Slovak family businesses. AD ALTA-Journal of Interdisciplinary Research, 9(1), 222-226

37. Ochoa Zuluaga, G. I. (Ed.). (2008). Turismo en la amazonía: entre el desarrollo convencional y las alternativas ambientales amigables. Bogotá s.l: Editora Guadalupe. 
38. Ojeda Revah, M. (2014). América Latina y la Gran Guerra. Un acercamiento a la cuestión. Política y Cultura, (42). Retrieved from http://www.redalyc.org/resumen.oa?id=26732736002

39. Organización Mundial del Turismo (Madrid, E. (2003). Turismo y atenuación de la pobreza. Madrid: Organización Mundial de Turismo.

40. Palacio, G. A. (2008). Del viaje al turismo en el paisaje colombiano en construcción: Naturaleza, género y civilización, 1850-1920. Retrieved from http://www.academia.edu/24244194/Del_viaje_al_turismo_en_el_paisaje_colo mbiano_en_construcci\%C3\%B3n_Naturaleza_g\%C3\%A9nero_y_civilizaci\%C3 $\%$ B3n_1850-1920

41. Pérez-Gálvez, J. C., Torres León, L., Muñoz-Fernández, G. A., \& López-Guzmán, T. (2018). El turista cultural en ciudades patrimonio de la humanidad de Latinoamérica. El caso de Cuenca (Ecuador). Turismo y Sociedad, 22, 105. https://doi.org/10.18601/01207555.n22.06

42. Population City. (2018). Bahía Solano-Población. Retrieved September 25, 2018, from http://poblacion.population.city/colombia/bahia-solano/

43. República de Colombia Ministerio de Comercio, Industria y Turismo. (2016). Plan de Desarrollo Turístico Departamento del Chocó.

44. República de Colombia Ministerio de Trabajo. (2013). Perfil Productivo del Municipio Bahía Solano.

45. Revilla, M. R. G., \& Moure, O. M. (2017). Turismo científico y ciudades del futuro. International journal of scientific management and tourism, 3(1), 123-130.

46. Richards, G. \& Munsters, W. (2010). Cultural tourism research methods. CABI Publishing. Great Britain. Wallinghton.

47. Rivera, M. A. (2017). The synergies between human development, economic growth, and tourism within a developing country: An empirical model for ecuador. Journal of Destination Marketing \& Management, 6(3), 221-232. https://doi.org/10.1016/j.jdmm.2016.04.002

48. Roldán Luna, D. (2003). El Plan de Desarrollo 2002-2006 "Hacia un Estado Comunitario": algunas implicaciones para el conjunto de la economía y su proyección al campo colombiano. Retrieved September 14, 2018, from Revista Sociedad y Economía website: http://www.redalyc.org/pdf/996/99617936013.pdf

49. Rozo, E., \& Vélez, M. (2016). Debates contemporáneos sobre el turismo: Tomo II. Reflexiones y dinámicas en los lugares turísticos: dilemas éticos, imaginarios sociales y prácticas culturales. Retrieved from https://www.overdrive.com/search?q=DDA73674-CD1C-44B8-AFEFE7A8876A4F14

50. Sánchez-Zárate, P. U. (2016). Diseño de servicios: una estrategia para el etnoturismo. Gestión y Ambiente, 19(2), 289-301.

51. Saptorini, H., \& Viviani, D. (2018). Mapping of Affordance and Activity as the Biophilic Design Principle of Blue Lagoon Tourism Area Yogyakarta. SHS Web of Conferences, 41, 06003. https://doi.org/10.1051/shsconf/20184106003

52. Tobón Perilla, S. M., \& Tobón Perilla, N. (2013). Revista Turismo y Sociedad UExternado. Retrieved September 15, 2018, from Anuario Turismo y Sociedad website:

https://revistas.uexternado.edu.co/index.php/tursoc/article/view/3724/4075 
53. Torralba, L. T. (2015). La dimensión turística del patrimonio cultural de la ciudad de Lorca (Murcia, España). Cuadernos de Turismo, (36), 389-414. https://doi.org/10.6018/turismo.36.231061

54. Tosun, C. (2005). Stages in the emergence of a participatory tourism development approach in the Developing World. Geoforum, 36(3), 333-352. https://doi.org/10.1016/j.geoforum.2004.06.003

55. Trujillo Quintero, H. F. (2014). Realidades de la Amazonía Colombiana: Territorio, Conflicto Armado y Riesgo Socioecológico. Revista ABRA, 34(48). https://doi.org/10.15359/abra.34-48.4

56. Viana, D. F., Halpern, B. S., \& Gaines, S. D. (2017). Accounting for tourism benefits in marine reserve design. PLOS ONE, 12(12), e0190187. https://doi.org/10.1371/journal.pone.0190187

57. visitcolombia. (2018). Colombia, El riesgo es que te quieras quedar (País). Retrieved from https://www.youtube.com/watch?v=8kUU-DWOqmI

58. Volgger, M., Herntrei, M., Pechlaner, H., \& Pichler, S. (2018). Cooperative resorts: An analysis of creative integration strategies in community destinations. Journal of Destination Marketing \& Management. https://doi.org/10.1016/j.jdmm.2018.04.002

59. Xiang, Z., \& Fesenmaier, D. R. (Eds.). (2017). Analytics in Smart Tourism Design. https://doi.org/10.1007/978-3-319-44263-1

60. Zheng, W., Liao, Z., \& Qin, J. (2017). Using a four-step heuristic algorithm to design personalized day tour route within a tourist attraction. Tourism Management, 62, 335-349. https://doi.org/10.1016/j.tourman.2017.05.006

\section{Brief description of Author/Authors:}

Ing. Gabriela Antošová, Ph.D.

Affiliation: Department of economics, The College of Business in Prague, Czech Republic, Spálená 76/14, 11000 Prague, antosova@ vso-praha.eu, http://orcid.org/00000001-5330-679X. Research Fellow and Assistant Professor at The Private University College of Business in Prague, also scientific member of committee Academia Europa Nostra and CITUR. She focuses on the management of the endogenous potentials in the regional and social development, local tourism and multidisciplinary content of methodological approaches in research. Currently she is a main coordinator and researcher from Czech Republic of the project "Bahía Solano como destino turístico Actualización del plan turístico".

\section{Mgr. Jefferson Enrique Arias Gómez, Ph.D.}

Affiliation: Universidad Corporación Universitaria Minuto de Dios, Cra. 74 \#81 C-05, Bogotá, Postal Code. 1110. Rector of the Universidad Minuto de Dios. Graduated in Ph. D. degree in Management at Mondragón University (Spain) with a postdoctoral study in Education. His main professional experiences are in education and management. Previously, he was appointed as the dean of Management Faculty. He focuses on Management topics at: Universidad Libre, Universidad Militar Nueva Granada and in postgraduate programs of Universidad Minuto de Dios and research on Social Management, Micro-finance, Social Entrepreneurship, Social Innovation. 
Mgr. Helmuth Yesid Arias Gómez, Ph.D.

Affiliation: Department of economics, The College of Business in Prague, Czech Republic, Spálená 76/14, 11000 Prague, Received a Ph.D. degree in Applied Economic Analysis and Economic History at University of Seville (Spain). Actual affiliation: University College of Business in Prague. He has publications in the fields of Regional Economics, Macroeconomics, New Economic Geography and Economic Theory. He developed research topics in: Regional Economics, Manufacturing, Location Theory and New Economic Geography. 